\title{
Możliwości wykorzystania metod socjologicznoprawnych do badania sposobu podejmowania decyzji na poziomie lokalnym Studium przypadku
}

Zjawiska prawne mogą być badane różnego rodzaju metodami badawczymi. Jednym ze sposobów jest stosowanie metod socjologicznych. Socjologia prawa w znaczeniu szerokim oznacza właśnie zastosowanie metod i technik socjologicznych do badania prawa ${ }^{1}$. W znaczeniu wąskim w wersji prawniczej socjologia prawa jest zespołem twierdzeń generalizujących systematyczne bądź akcydentalne obserwacje dotyczące zjawisk prawnych w ich aspekcie społecznym. Tak więc socjologia prawa ma przyczynić się do poznawania genezy i funkcjonowania poszczególnych instytucji prawnych w ramach danego porządku prawnego. Twierdzenia socjologii prawa mają służyć do rozstrzygania problemów socjotechnicznych stawianych przez praktykę prawniczą ${ }^{2}$.

Jednym z obszarów socjologicznoprawnych zainteresowań jest badanie sposobu podejmowania decyzji na poziomie lokalnym przez administrację samorządową. Samorząd jest formą organizacji wyodrębnionej grupy społecznej, dzięki której może ona decydować w granicach prawa o istotnych dla niej sprawach, działając bezpośrednio lub za pośrednictwem demokratycznie wybranego i funkcjonującego przedstawicielstwa. Podmiotem samorządu jest określona społeczność wyodrębniona na podstawie wspólnych interesów ${ }^{3}$.

Administracja samorządowa, wydając decyzje lokalne, prowadzi działalność reglamentacyjną (dzielenie dóbr) oraz świadczącą (regulowanie sposobu korzystania z tych dóbr). Administracja samorządowa zajmuje się też stosowaniem prawa (wydawaniem decyzji administracyjnych) ${ }^{4}$. Jest skierowana zarówno na ochronę interesu publicznego, np. interesu gminy jako wspólnoty

1 A. Pieniążek, M. Stefaniuk, Socjologia prawa. Zarys wykładu, Kraków 2003, s. 100.

2 Ibidem, s. 101.

3 J. Szreniawski, Wstęp do nauki administracji, Lublin 2000, s. 71.

4 Z. Łuniewska, B. Jaworska-Dębska, R. Michalska-Badziak, E. Olejniczak-Szałowska, M. Stahl, Prawo administracyjne. Pojęcia, instytucje, zasady w teorii i orzecznictwie, Warszawa 2000, s. $17-19$. 
lokalnej, jak i konkretnej osoby, np. mieszkańca danej gminy. Administracja samorządowa nie działa w społecznej próżni, lecz funkcjonuje w określonym otoczeniu społecznym. Jej działanie we współczesnym społeczeństwie może być wyznaczone przez kulturę, a więc poprzez określone wspólne wartości, zidentyfikowane w ramach pewnej grupy społecznej; wartości, które mogą być ograniczone przez rywalizację grup społecznych. Można przyjąć założenie, że administracja samorządowa, wydając decyzje lokalne, powinna kreować wartość publiczną za pomocą usług publicznych, realizowanych przez swe organy. Powinna przy tym dysponować odpowiednim potencjałem organizacyjnym (ludzie, wewnętrzna struktura, więź społeczna, komunikacja społeczna i urządzenia techniczne) oraz poparciem mieszkańców. Wydaje się, iż administracja samorządowa działa skutecznie, jeśli w rezultacie podejmowania decyzji wypełnia cele ustawowe i spełnia oczekiwania swoich klientów, którymi są wspólnoty lokalne.

Podstawowym obowiązkiem władzy lokalnej (samorządowej i administracji rządowej w terenie) powinno być regulowanie poprzez prawo stosunków społecznych. Władza ma do dyspozycji różne metody regulacji, od wydania arbitralnej decyzji po konsultacje społeczne i oparcie decyzji na badaniach społecznych. Problemem jest znalezienie jak najlepszego rozwiązania problemu społecznego czy funkcjonującego konfliktu społecznego. Aby proces regulacji poprzez prawo był skuteczny, władza musi brać pod uwagę stopień internalizacji norm prawnych. Jednym z pól badawczych socjologii prawa jest badanie społecznego działania prawa. Zwykle działanie prawa polegające na czynieniu z niego użytku przez władzę lokalną polega na instrumentalnym podejściu do niego i posługiwaniu się prawem jako środkiem do osiągnięcia zamierzonych celów, często bez oglądania się na opinię społeczną. Oczywiście, takie podejście do korzystania ze swych uprawnień przez władzę jest ograniczone samym prawem czy też ustalonymi normami społecznymi (moralnymi, obyczajowymi i zwyczajowymi). Taki instrumentalny model działania prawa polega na ingerencji prawa $\mathrm{w}$ coraz to nowe obszary stosunków społecznych i cechuje go daleko posunięte sterowanie scentralizowane, które przesądza zarówno o wytyczeniu celów, jak i doborze środków do ich realizacji. Działanie prawa oparte jest na przymusie. Taki model jest związany z pozytywizmem prawniczym i argumentacją logiczno-empiryczną. Jednakże model ten przeżywa kryzys, polegający na odrzuceniu czy też dezaprobacie prawa przez członków społeczeństwa, szczególnie na poziomie lokalnym. Model instrumentalny działania prawa stanowi również czynnik demobilizujący aktywność społeczną. Społeczeństwo lokalne z coraz większym trudem radzi sobie z samodzielnym rozwiązywaniem podstawowych problemów, oczekując ich rozwiązania przez władzę publiczną. Może to powodować nieskuteczność działania prawa w wielu dziedzinach życia społecznego, w związku z tym w demokratycznym państwie prawnym popularność zdobywa drugi model działania prawa - model 
interakcyjny. W nim regulacja poprzez prawo ma polegać na stworzeniu warunków dla wzajemnego komunikowania się władzy i społeczeństwa oraz wypracowaniu konsensualnych sposobów rozwiązywania problemów społecznych 5 .

Analizując zatem sposoby podejmowania decyzji lokalnych przez organy administracji samorządowej, należy podkreślić zainteresowanie teoretyków i socjologów prawa rozważaniami teoretycznymi i badaniami empirycznymi nad wpływem opinii publicznej na procesy związane ze społecznym działaniem prawa i podejmowaniem decyzji politycznych na podstawie obowiązującego prawa. Problem ten przejawia się w poszukiwaniu odpowiedzi na pytanie o rolę opinii publicznej w procesie decyzyjnym władzy lokalnej. Z kolei nabiera on szczególnego wydźwięku w warunkach istnienia konfliktu interesów pomiędzy władzą samorządową a społecznością lokalną oraz pomiędzy różnymi sformalizowanymi i nieformalnymi grupami społecznymi w ramach społeczności lokalnej.

W doktrynie podkreśla się, że w sytuacji, gdy organy władzy zlecą przeprowadzenie badania opinii publicznej, powinny przeanalizować wyniki tych badań i wyciągnąc $\mathrm{z}$ nich istotne wnioski w celu podjęcia trafnych decyzji ${ }^{6}$. W ogólnym rozumieniu decyzja to dokonywanie wyboru jednego wariantu spośród kilku możliwych. Proces decyzyjny polega na wyborze jednego spośród wielu rozpoznanych i uznanych za możliwe wariantów przyszłego działania, któremu władza przypisuje największą użyteczność w dążeniu do wyznaczonego celu.

W działaniu organów władzy samorządowej podjęcie decyzji lokalnej może być proste jedynie wówczas, gdy sytuacja, w której znajdzie się organ władzy lokalnej, będzie jasna i określona. Niestety, takie sytuacje zdarzają się rzadko, więc w razie konfliktu społecznego powstaje pewna trudność w podjęciu decyzji lokalnej. Proces podejmowania decyzji polega zatem na rozpoznaniu i zdefiniowaniu istoty sytuacji decyzyjnej, opracowaniu i analizie zbioru wariantów rozwiązań, wyborze spośród nich najlepszego oraz wprowadzeniu go do realizacji. Podejmowanie decyzji jest jednym $\mathrm{z}$ najważniejszych elementów procesu zarządzania w administracji. Jest to proces, dzięki któremu poprzez organizowanie, planowanie, kierowanie i kontrolę, realizowane są najważniejsze cele strategiczne społeczeństwa lokalnego. Decyzje administracji - jako akty woli osób je podejmujących - organizują i stymulują zachowanie mieszkańców, od których świadomości i zaangażowania zależy efektywność działania całej organizacji

5 M. Borucka-Arctowa, Regulacja życia społecznego poprzez prawo a internalizacja normy prawnej, [w:] K. Opałek et al., Prawo i polityka, Warszawa 1988, s. 70-71.

6 T. Sasińska-Klas, Opinia publiczna w systemie demokratycznym, [w:] M. Borucka-Arctowa et al., Prawo - władza - spoleczeństwo - polityka. Księga jubileuszowa Profesora Krzysztofa Pałeckiego, Toruń 2006, s. 425. 
i społeczeństwa jako całości. Stąd też wydaje się, że każda decyzja władzy może być narzędziem służącym do osiągania konsensusu społecznego. Decyzja lokalna powinna więc być skuteczna i efektywna, tzn. zapewnić administracji równowagę względem otoczenia społecznego, rozwój potencjału ludzkiego i materialnego oraz optymalne efekty ekonomiczne.

Podstawą istnienia ładu społecznego w społeczności lokalnej jest współpraca, umiejętność uzgadniania rozbieżnych interesów, konsensus, akceptowanie przez członków zbiorowości wspólnej hierarchii wartości. Kiedy władza dąży do osiągnięcia kompromisu w relacjach grup społecznych o przeciwstawnych interesach, wówczas może nastąpić zmiana społeczna w kierunku równowagi społecznej. W przeciwnym wypadku może dojść do działań destrukcyjnych, konfliktowych, które mogą powodować dezorganizację, zagrażającą rozpadem określonej zbiorowości oraz powstaniem negatywnych zjawisk społeczno-patologicznych. Szczególny rodzaj trudności w podejmowaniu decyzji zachodzi w sytuacji konfliktu interesów społecznych. Przed podjęciem decyzji władza powinna przeanalizować bieżącą sytuację, w sposób nieintuicyjny podejmując próbę odkrycia i zrozumienia jej niejawnych aspektów. W tym przypadku funkcję instrumentalną wobec poznania i kształtowania sfery rozwiązań praktycznych mogą skutecznie pełnić badania opinii publicznej. Wyniki z przeprowadzonych badań mogą pozwolić na sformułowanie wniosków i wyprowadzenie dyrektyw niezbędnych do podjęcia trafnych decyzji. Sama trafna decyzja zapewnia administracji samorządowej równowagę względem otoczenia społecznego i rozwój na poziomie potencjału ludzkiego, materialnego oraz ekonomicznego, z drugiej strony zaś osiągnięty kompromis w relacjach grup społecznych o przeciwstawnych interesach stymuluje zmianę społeczną w kierunku przywrócenia równowagi społecznej i integracji systemu lokalnego. Pozwala na uniknięcie nawarstwienia relacji konfliktowych i eskalacji działań destrukcyjnych, które w dłuższej perspektywie czasowej powodują dezorganizację oraz stanowią zagrożenie dla istnienia i funkcjonowania określonej zbiorowości. Natomiast podjęcie w warunkach lokalnych decyzji, która jest społecznie nieakceptowana, może spowodować powstanie konfliktu społecznego.

Konflikt jest pojęciem niezwykle złożonym i definiowanym na różne sposoby. W teorii socjologicznej wyróżnia się trzy podstawowe ujęcia konfliktu: behawioralne, psychospołeczne i socjologiczne? ${ }^{7}$. Konflikt w ujęciu behawioralnym obejmuje zachowania podmiotów o przeciwstawnych dążeniach (interesach). Konflikt w sensie psychospołecznym dotyczy nie zachowań, lecz napięć społecznych, odzwierciedlonych w psychice jednostek, jakie powstały w wyniku uświadomienia sobie przez strony przeciwstawności ich pozycji w danej strukturze społecznej. Konflikt w ujęciu socjologicznym oznacza zaś powstanie

7 J. Mucha, Jak badać dynamikę i konflikt w spoleczeństwie polskim, „Studia Socjologiczne” 1985, nr 3-4, s. 141-145. 
antagonizmu jako obiektywnej cechy strukturalnej danej sytuacji społecznej, polegającej na niemożności równoczesnej realizacji wszystkich interesów i dążeń występujących w danej społeczności ${ }^{8}$.

W literaturze przedmiotu pod pojęciem konfliktu rozumie się również układ skierowanych przeciwko sobie zachowań dwóch podmiotów społecznych (jednostek, grup bądź ich organizacji), z których każdy dąży do realizacji własnych celów (interesów) i napotyka na przeciwdziałanie pozostałych uczestników konfliktu9. Równocześnie podkreśla się, że świat organizacji jest dialektyczną jednością konfliktu i współdziałania. Bowiem w większości sytuacji zrealizowanie interesów wysuwanych przez jednostki i grupy jest możliwe jedynie poprzez współdziałanie ${ }^{10}$. Wystąpienie konfliktu w społeczeństwie powoduje dezorganizację społeczną. Jego zakończeniem i rozstrzygnięciem zainteresowane mogą być więc zarówno strony konfliktu, jak i otoczenie społeczne. Konflikt ujawniony wobec otoczenia społecznego i poddany jego obserwacji przekształca się w spór. Z kolei spór wymusza reakcję otoczenia na zaistniałą sytuację. Różnego rodzaju spory prawne i polityczne o charakterze interpersonalnym, międzygrupowym, a także pomiędzy podmiotami władzy publicznej i obywatelami, należą do kategorii zjawisk społecznych różnicujących sieć stosunków społecznych, na których opiera się dynamika życia społecznego. Jeśli spór zagraża interesom społeczności, pojawia się potrzeba przywrócenia zachwianej równowagi. Wówczas zostają uruchomione formalnoprawne i zwyczajowe (rutynowe) mechanizmy oraz techniki jego kontroli (kanalizacji, rozwiązywania) bądź wypracowywane są spontanicznie - przez zaangażowane strony w trakcie interakcji - nowe i niestandardowe. Strony mogą rozwiązać spór w sposób pokojowy (a więc z wykluczeniem przemocy) i niewładczy (tj. bez arbitralnego narzucenia stronom decyzji kończącej spór, wspartego przymusem bądź autorytetem). Strony mogą także rozstrzygnąć spór, przez co należy rozumieć proces arbitralnego (opartego na przemocy, przymusie bądź autorytecie) narzucania decyzji kończącej spór w stosunku do jednej lub obu stron sporu. Może to być wynikiem interwencji trzeciego podmiotu w spór, dysponującego siłą lub uprawnieniami władczymi w stosunku do stron sporu.

Jednakże działalność organów władzy samorządowej w środowisku lokalnym związana $\mathrm{z}$ wydawaniem decyzji lokalnych powinna być raczej efektem kompromisu między granicą prawa a granicą słuszności interesów poszczególnych grup społecznych. Podkreślić należy, że stosując prawo, organ władzy lokalnej zgodnie z art. 7 k.p.a. ${ }^{11}$ bierze pod uwagę każdy interes społeczny, natomiast

8 J. Mucha, Konflikt społeczny, [w:] W. Kwaśniewicz (red.), Encyklopedia socjologii, t. 2: $K-N$, Warszawa 1999, s. 63 i n.

9 A. Korybski, Alternatywne rozwiqzywanie sporów w USA, Lublin 1993, s. 20.

${ }^{10}$ H. Groszyk, A. Korybski, Konflikt interesów i prawo, Warszawa 1990, s. 98.

${ }^{11}$ Ustawa z dnia 14 czerwca 1960 r. - Kodeks postępowania administracyjnego, t.j. Dz. U. 2000, nr 98, poz. 1071, z późn. zm. 
interes jednostki w przypadku postępowania administracyjnego musi być słuszny. Również w przypadku konfliktu społecznego nie każdy interes jednostki ma być uwzględniany przez organ administracji samorządowej, lecz taki, który może być uznany za słuszny. Słuszny interes nie stoi w sprzeczności ani z prawem, ani z zasadami współżycia społecznego. W związku z tym, że w podejmowaniu decyzji lokalnej trudno jest odnieść się do interesu, który jednostka subiektywnie, według własnych potrzeb, uznaje za słuszny, organ zwykle posługuje się kryteriami obiektywnymi i przyjmuje, iż kieruje się słusznym interesem jednostki, gdy wydaje decyzję lokalną według przewidzianych prawem procedur (sprawiedliwość proceduralna) ${ }^{12}$. Zatem organ władzy samorządowej powinien brać pod uwagę nie tylko słuszność obiektywną (zgodność z prawem), ale i słuszność subiektywną (zgodność z wartościami kulturowymi grup społecznych). Co więcej, powinien być otwarty na potrzeby otoczenia społecznego. Podejmowanie decyzji w oparciu o przymus polegający na tym, iż w sytuacji konfliktu społecznego władza samorządowa podejmuje decyzje lokalne sama, jest naruszeniem porządku społecznego. Oczywiście, innym wymiarem władzy lokalnej jest stosowanie zabiegów prowadzących do niedopuszczenia do otwartego konfliktu lub do eskalacji konfliktu już istniejącego.

Konflikt społeczny może pojawić się na tle sprzecznych interesów dwóch grup społecznych i konieczności rozstrzygnięcia konfliktu przez organ władzy samorządowej w interesie nie tylko poszczególnych grup, ale całej społeczności lokalnej. Samo pojęcie władzy należy rozumieć jako moc do podejmowania rozstrzygających decyzji, rozumianych zarówno jako gra, gdzie jedna strona zyskuje, a druga strona traci, jak i gier o sumie niezerowej, w których wszyscy uczestnicy konfliktu mogą jednocześnie wygrać. W takim przypadku sens władzy, rozumianej jako zdolność osiągania celów zbiorowych, polega właśnie na tym, aby wszyscy uczestnicy konfliktu mogli przynajmniej w jakimś stopniu zyskaćl ${ }^{13}$.

Analizując metody badań, których przedmiotem jest administracja, należy podkreślić, że dzieli się je na metody dotyczące zbierania danych (gromadzenia materiału empirycznego) oraz metody dotyczące opracowywania zebranych danych. Do pierwszej grupy metod w socjologii zalicza się: obserwację, wywiad, ankietę, eksperyment, analizę dokumentów. Natomiast do drugiej grupy - metodę statystyczną i metodę monograficzną. W trakcie prowadzenia badań możliwe jest stosowanie jednej lub kilku metod jednocześnie. Materiał informacyjny zdobyty dzięki zastosowaniu poszczególnych metod powinien być oceniany pod względem przydatności i prawdziwości, jednakże wszelkie weryfikacje nie

${ }^{12}$ S. Pilipiec, Kultura prawna a prawo obywatela do ochrony stusznego interesu, „Studia Iuridica Lublinensia" 2011, t. XV, s. 150-151.

${ }^{13}$ M. Ziółkowski, Władza - wymiary, funkcje oraz społeczne przekonania na jej temat, [w:] K. Skarżyńska (red.), Podstawy psychologii politycznej, Poznań 2002, s. 145. 
powinny polegać na tendencyjnym doborze czy też interpretowaniu wyników badań. Również w badaniach nad administracją należy unikać wydawania sądów wartościujących, a korzystać raczej z odniesień do wartości.

Badania opisywane w niniejszym tekście dotyczyły konkretnego przypadku podejmowania decyzji przez administrację samorządową w sytuacji istnienia konfliktu w otoczeniu społecznym w Lubartowie w październiku 2011 r. Władze Lubartowa powołały trzyosobowy zespół ekspercki złożony z pracowników Uniwersytetu Marii Curie-Skłodowskiej w Lublinie ${ }^{14}$. Zespół miał za zadanie przeprowadzić proces ankietyzacji mieszkańców Lubartowa mających czynne prawo wyborcze. Badanie było związane z konfliktem społecznym w przedmiocie budowy Zakładu Zagospodarowania Odpadów (ZZO) w lokalizacji ulic: Gazowej, Lipowej i Nowodworskiej w Lubartowie. Władze samorządowe musiały wydać decyzję lokalną związaną z podjęciem budowy ZZO lub powstrzymaniem tej budowy. Najważniejszym celem procesu ankietyzacji było uzyskanie opinii pełnoletnich mieszkańców Lubartowa co do budowy i lokalizacji Zakładu Zagospodarowania Odpadów. Eksperci przygotowali zaaprobowaną przez władze miasta wersję ankiety. Składała się ona z dwóch części. Pierwsza obejmowała pięć pytań merytorycznych odnoszących się do kluczowych aspektów problemu realizacji inwestycji w postaci Zakładu Zagospodarowania Odpadów, istotnych zarówno z punktu widzenia społecznego, jak i z punktu widzenia polityki miasta. Pytania objęły następujące sfery: ocenę stopnia znajomości problemu, opinię w przedmiocie istnienia zakładu w ogóle, kwestię finansowania inwestycji, ocenę stopnia poczucia zagrożenia mieszkańców w związku z funkcjonowaniem zakładu w granicach miasta i w końcu opinię mieszkańców co do lokalizacji zakładu w lokalizacji ulic: Gazowej, Lipowej, Nowodworskiej w Lubartowie. Druga część ankiety obejmowała wybrane dane socjodemograficzne: płeć respondentów, ich wiek, status na rynku pracy i samoocenę sytuacji finansowej. Zasadność pytań drugiej części ankiety wiązała się z potrzebą ustalenia uwarunkowań jakościowego zróżnicowania opinii społecznej ${ }^{15}$.

Ankieta została przeprowadzona w dniach od 1 do 15 października $2011 \mathrm{r}$. przez 23 ankieterów na projektowanej próbie około 18 tys. mieszkańców Lubartowa. Skala przedsięwzięcia (ankietyzacja 18 tys. mieszkańców mających prawa wyborcze spośród wszystkich ówczesnych mieszkańców Lubartowa) wymagała nie tylko przygotowania logistycznego, lecz także współpracy wszystkich

${ }^{14} \mathrm{~W}$ skład interdyscyplinarnego zespołu badawczego wchodzili: dr Marta Łacek - socjolog z Wydziału Filozofii i Socjologii UMCS w Lublinie oraz dr Bartosz Liżewski z Katedry Teorii i Filozofii Prawa i dr Sławomir Pilipiec z Zakładu Socjologii Prawa (obaj z Wydziału Prawa i Administracji UMCS w Lublinie).

${ }^{15}$ B. Liżewski, M. Łacek, S. Pilipiec, Mieszkańcy Lubartowa wobec budowy i lokalizacji zakładu zagospodarowania odpadów (ZZO). Ekspertyza z procesu ankietyzacji $w$ dniach 1-15 października 2011 r., opublikowana na stronie Urzędu Miasta Lubartów; www.lubartów. pl/?temat=101336 (dostęp: 11.10.2012). 
zainteresowanych budową lub powstrzymaniem budowy Zakładu Zagospodarowania Odpadów. Władze lokalne, powołując zespół badawczy, wyszły z założenia, że w społeczeństwie obywatelskim jednym z najważniejszych elementów jest komunikacja społeczna i każdy członek wspólnoty lokalnej powinien mieć prawo do wypowiedzenia się oraz zajęcia stanowiska w kwestiach, które go dotyczą lub mogą dotyczyć. Wobec założenia, że problemy należy rozwiązywać, a nie udawać, że nie istnieją, przygotowanie ankiety było związane z szerokim uczestnictwem wszystkich zainteresowanych tą - wywołującą kontrowersje społeczne - sprawą. Zgoda wszystkich zainteresowanych na przeprowadzenie ankiety bez watpienia wpłynęłaby pozytywnie na aprobatę procesu, spokojny sposób jego wykonania, wyłączałaby też wszelkie spekulacje co do prawidłowości jego przebiegu. Niestety, konflikt społeczny wpłynął bezpośrednio na postawy zwolenników i przeciwników ZZO. Mimo wszystko zespół ekspertów realizował swoje obowiązki $\mathrm{w}$ zakresie posiadanego materiału empirycznego w postaci ankiet oraz czuwał nad prawidłowością i obiektywnością procesu ankietyzacji. Poza zakresem oceny zespół pozostawił kwestię zewnętrznej agitacji przeciwników budowy ZZO (tzw. „,anty-ankieta”), na którą nie miał wpływu ${ }^{16}$. Należy zauważyć, iż mogła ona w jakimś stopniu wpłynąć na opinię społeczną, ale trudno wskazać, w jakim. Wydaje się, że twórcy tej „,anty-ankiety” (niezależnie od tego, kim byli), realizowali swoje zamierzenia jako wyraz skrajnej negacji dla projektowanej lokalizacji ZZO lub też zdecydowali się na takie działanie ze względów politycznych bądź innych interesów własnych czy specyficznej grupy odniesienia ${ }^{17}$.

Ostatnim etapem szeroko ujętego procesu ankietyzacji była diagnoza wyników. Uprzednio zakodowane w bazie danych odpowiedzi poszczególnych respondentów wymagały analizy statystycznej, która nie ograniczała się wyłącznie do wskazania wartości rozkładów procentowych odpowiedzi na poszczególne pytania. Istotą diagnozy było: 1) określenie struktury powiązań pomiędzy odpowiedziami na poszczególne pytania; 2) próba wyjaśnienia statusu odpowiedzi „nie mam zdania” i zakreślenia innego typu; 3) powiązanie odpowiedzi z kategoriami soocjodemograficznymi; 4) ukazanie spójności opinii społecznych w obrębie grup statystycznych.

Podczas 12 dni prac terenowych ankieterom udało się nawiązać kontakt z 11932 mieszkańcami, co stanowiło 64,1\% zakładanej przez władze Lubartowa próby 18618 osób. Ankiety wypełniło 10614 osób, tj. 57\% mieszkańców. Odmówiło wypełnienia ankiety - w różny sposób to uzasadniając - 1318 osób, tj. 7,1\% mieszkańców. W wyniku badań ustalono, że blisko 70\% mieszkańców Lubartowa chce budowy Zakładu Zagospodarowania Odpadów w Lubartowie.

${ }^{16}$ „Anty-ankieta” miała charakter pisemnej ulotki zawierającej treść pytań z oryginalnej ankiety, z równoczesnym wskazaniem sposobu zaznaczenia odpowiedzi, która zdaniem autorów (zapewne przeciwników ZZO) jest jedynym słusznym wyborem.

${ }^{17}$ B. Liżewski, M. Łacek, S. Pilipiec, op. cit. 
„Tak” odpowiedziało 67,4\% (7150 osób), „nie” - 25\% (2600 osób), „nie mam zdania" - 6,9\% (730 osób). Jednakże na ostatnie pytanie dotyczące konkretnej lokalizacji w Lubartowie w sąsiedztwie ulic Lipowej, Gazowej, Nowodworskiej nieco ponad połowa ankietowanych wypowiedziała się przeciwko takiej lokalizacji. „Tak” odpowiedziało $36,1 \%$ osób, „nie” - 51,1\% osób, „nie mam zdania” - 11\% osób. Wyniki te doprowadziły do powstrzymania budowy ZZO w Lubartowie i pozwoliły władzy samorządowej na rozpoczęcie poszukiwania alternatywnej lokalizacji $Z_{Z} \mathrm{O}^{18}$.

W przeprowadzonych badaniach istotna była postawa mieszkańców, czyli ich masowe uczestnictwo w procesie ankietyzacji, ponieważ wpływało to na reprezentatywność wyniku. Władze miasta od samego początku przekonywały, że chociaż z prawnego punktu widzenia nie ma przeciwwskazań do rozpoczęcia inwestycji, to jednak brak akceptacji społecznej może być traktowany jako swoiste nadużycie posiadanej legitymacji do sprawowania władzy w mieście. Dlatego wiedza na temat stanowiska szerokiej opinii społecznej miała ogromne znaczenie dla władz samorządowych w procesie kształtowania ostatecznej decyzji co do losów spornej inwestycji.

Badania te można uznać za przykład skutecznego wykorzystania metod socjologicznych do badania działania administracji polegającego na wydawaniu decyzji lokalnych oraz badania stopnia zaangażowania lokalnej wspólnoty w proces podejmowania decyzji przez administrację samorządową. Decyzja władz wykorzystania zespołu eksperckiego pracowników Uniwersytetu Marii Curie-Skłodowskiej w Lublinie jest przykładem dobrej praktyki przybliżania sfery publicznej (działania władzy) do sfery prywatnej (mieszkańców miasta). Mając na uwadze konieczność podjęcia pilnej decyzji o realizacji bądź wstrzymaniu planowanej inwestycji (ZZO), budzącej niepokój i sprzeciw części mieszkańców, władze postanowiły odwołać się do zdania opinii publicznej. Badanie ankietowe polegające na próbie bezpośredniego dotarcia do wszystkich pełnoletnich mieszkańców Lubartowa w skali ogólnopolskiej było przedsięwzięciem oryginalnym i zgodnym z koncepcją budowania społeczeństwa obywatelskiego. Mimo że zarówno zwolennicy budowy ZZO, jak i jej przeciwnicy oraz zespół ekspertów zdawali sobie sprawę, że przeprowadzone badania społeczne nie mają dla władzy lokalnej charakteru prawnie wiążącego, to jednak dla wszystkich było oczywiste, że w zaistniałej sytuacji społecznej, prawnej i ekonomicznej ostateczna decyzja samorządowa powinna być zgodna z oczekiwaniami społeczności. Najważniejszym problemem we wstępnej fazie badań było przekonanie mieszkańców, że ich głos będzie wzięty pod uwagę $\mathrm{w}$ procesie wydawania decyzji lokalnej przez władze samorządowe. Badania wykazały, że mieszkańcy Lubartowa są zasadniczo za budową Zakładu Zagospodarowania Odpadów, jednak nie zgadzają się na lokalizację tej budowy w obrębie ulic: Lipowej, Gazowej i Nowodworskiej.

${ }^{18}$ Ibidem. 
Odpowiedź pierwsza wskazuje na społeczne poparcie dla inwestycji w ogóle. Jednak akceptacja dla budowy i istnienia ZZO przy odrzuceniu przez mieszkańców jego planowanej lokalizacji mogła być wskazówką dla władz samorządowych.

Proces ankietyzacji miał więc uzmysłowić władzom Lubartowa, jakie jest rzeczywiste stanowisko mieszkańców w sprawach objętych pytaniami ankiety. Po przeprowadzeniu przedmiotowych badań istotne było ustalenie, czy badania były skuteczne, a więc czy władze lokalne uwzględniły, a jeśli tak, to w jakim stopniu, wyniki ankiety. W trakcie realizacji procesu ankieterzy wielokrotnie informowali, że respondenci wyrażali wątpliwość, a niekiedy nawet stwierdzali kategorycznie, że ich głos nie będzie miał żadnego znaczenia. To przekonanie było łączone z tezą, iż decyzja w przedmiocie ZZO została już podjęta na szczeblu miejskim. Sama ankieta zaś ma być formą uspokojenia zarówno przeciwników inwestycji, jak i całej opinii społecznej.

Najważniejszym problemem, z którym musiała się uporać władza samorządowa, było zagadnienie lokalizacji ZZO. Władze chciały uzyskać społeczną aprobatę bądź dezaprobatę dla planowanej inwestycji. Każda decyzja podjęta przez władze samorządowe spotkałaby się z protestem. W przypadku podjęcia praworządnej decyzji zgodnej z prawem, ale niezgodnej z oczekiwaniami społecznymi, konflikt społeczny rozszerzyłby swój zasięg i nastąpiłaby dalsza polaryzacja stanowisk. Władze samorządowe wykazały się jednak dużym wyczuciem społecznym i dla akceptacji swej decyzji odwołały się nie tylko do praworządności (zgodności z prawem), lecz także do prawowitości swej decyzji1 ${ }^{19}$. Decyzja została oparta nie tylko na normach prawnych, ale również normach obyczajowych odnoszących się do tradycji konsultacji społecznych. Badania społeczne przeprowadzone w Lubartowie pozwoliły na osiagnnięcie przez władze lokalne dużego stopnia internalizacji decyzji związanej z budową ZZO.

Wyrażenie sprzeciwu społecznego wobec lokalizacji ZZO wykazuje niezwykłą istotność ankietowego pytania o potrzebę zbudowania ZZO dla Lubartowa w kontekście zmiany prawa związanego z zagospodarowaniem odpadów. W przedmiotowym przypadku zdecydowana większość respondentów wyraziła przekonanie o konieczności budowy takiego zakładu. Takie stanowisko mieszkańców było bardzo ważne, ponieważ oznaczało, że mieszkańcy Lubartowa chcą, aby zakład powstał, ale w innej lokalizacji. Uzyskane dane ankietowe okazały się bardzo istotne. Po pierwsze, pozwoliły na kontynuowanie procesu, który ma doprowadzić do powstania ZZO dla Lubartowa, ale w innej niż planowana lokalizacji. Po drugie, dzięki badaniom Fundusz Szwajcarsko-Polski zgodził się przesunąc środki na realizację inwestycji w innym terminie oraz $\mathrm{w}$ innej lokalizacji. Ta kwestia jest szczególnie ważna, gdyż pomoc finansowa w dużej zadeklarowanej kwocie jest koniecznym elementem inwestycji. Miasta Lubartów

${ }^{19}$ G. Woroniecka, Działanie polityczne. Próba socjologii interpretatywnej, Warszawa 2001, s. 71. 
po prostu nie byłoby stać na samodzielne jej sfinansowanie. Końcowym etapem procesu kształtowania decyzji stanowiło spotkanie w Ministerstwie Rozwoju Regionalnego w Warszawie w dniu 28 października 2011 r. pomiędzy przedstawicielami Funduszu Szwajcarsko-Polskiego a władzami Lubartowa. Uczestniczący w spotkaniu Szwajcarzy zgodzili się na dalszą współpracę z Lubartowem i zmianę lokalizacji ZZO. Ponadto, Fundusz Szwajcarsko-Polski podjął zobowiązanie o przyznaniu dodatkowych środków na adaptację projektu w nowej lokalizacji. Nowa lokalizacja zakładu to miejscowość Rokitno w gminie Lubartów. Potencjalna działka w Rokitnie znajduje się na terenie wysypiska śmieci. Zgodnie z ustaleniami, realizacja inwestycji ma być rozpoczęta w 2014 r., zaś oddana do użytku w 2015 r. $^{20}$

Podsumowując, należy podkreślić, że powyższe badania i oparta na nich decyzja dotycząca ZZO są dowodem na to, iż można skutecznie wykorzystywać metody socjologicznoprawne do badania sposobu podejmowania decyzji na poziomie lokalnym.

${ }^{20}$ Informacje uzyskane w rozmowie z zastępcą burmistrza Lubartowa, Radosławem Szumcem w październiku 2012 r. 